\title{
FORMULASI DAN EVALUASI SEDIAAN MASKER CLAY DARI KOMBINASI EKSTRAK ETANOL DAUN PEPAYA (Carita papaya L.) DAN LABU KUNING (Cucurbita moschata)
}

\author{
Ovalina Sylvia Br. Ginting ${ }^{1}$, Siti Susanti Siregar ${ }^{2^{*}}$ \\ 1,2,Prodi Farmasi, Fakultas Ilmu Kesehatan, Universitas Haji Sumatera Utara, Medan, Indonesia. \\ Email: sitisusantisir07@gmail.com \\ *corresponding author
}

\begin{abstract}
Abstrak
Kulit wajah merupakan bagian tubuh yang menggambarkan keseluruhan kondisi seseorang. Kulit wajah dirawat dengan baik karena merupakan perawatan dan rangsangan organ sensitif. Masker kulit wajah merupakan salah satu jenis kosmetik tradisional yang dapat digunakan sebagai perawatan wajah untuk menjaga kesehatan kulit wajah. Metode dalam penelitian ini menggunakan eksperimental. Metode penelitian ini adalah eksperimental. Penelitian ini meliputi, pembuatan orientasi basis masker clay, mengkombinasi ekstrak etanol daun papaya dan ekstrak labu kuning menjadi masker clay dengan variasi konsentrasi F0 (0:0), F1 (2:6), F2 (4:4), F3 (6:2) sediaan masker clay, uji evaluasi sediaan meliputi organoleptis, homogenitas, $\mathrm{pH}$, daya sebar, uji iritasi pada kulit sukarelawan, pengujian waktu kering dan uji antimikroba. Hasil penelitian menunjukan uji evaluasi sediaan masker clay ektrak daun papaya yang dikombinasi ekstrak etanol labu kuning pada uji homogenitas semua konsentrasi homogen, uji $\mathrm{pH}$ menunjukan semua konsentrasi sediaan memenuhi persyaratan $\mathrm{pH}$ yakni berkisar antara 5-8, pada uji iritasi semua sediaan tidak menimbulkan kemerahan dan pada uji waktu kering semua sediaan memenuhi persyaratan yakni dibawah 30 menit. Pada uji mikroba terhadap bakteri Propianibacterium acne menunjukan zona hambat yang baik pada sediaan masker F2 yaitu $16 \mathrm{~mm}$. Kesimpulan ekstrak etanol daun papaya yang dikombinasi dengan ekstrak etanol labu kuning menunjukan dapat digunakan sebagai alternatif kosmetik dan dapat dijadikan referensi untuk digunakan sebagai kosmetik alami.
\end{abstract}

Kata kunci: kombinasi, daun papaya, labu kuning, sediaan, masker clay

\begin{abstract}
Facial skin is a part of the body that describes the overall condition of a person. Facial skin requires special care, because facial skin is an organ that is sensitive to treatment and stimulation. Facial skin masks are one of the traditional types of cosmetics that can be used as facial treatments to maintain facial skin health. The method in this research is experimental. This research method is experimental. This research includes, making a clay mask base orientation, combining ethanol extract of papaya leaves and pumpkin extract into a clay mask with various concentrations of F0 (0:0), F1 (2:6), F2 (4:4), F3 (6:): 2) clay mask preparation, the evaluation test of the preparation includes organoleptic, homogeneity, $\mathrm{pH}$, spreadability, irritation test on volunteer skin, dry time test and antimicrobial test. The results showed that the evaluation test of papaya leaf extract clay masks combined with pumpkin ethanol extract in the homogeneity test of all homogeneous concentrations, the $\mathrm{pH}$ test showed that all concentrations of the preparations met the $\mathrm{pH}$ requirements which ranged from 5-8, in the irritation test all preparations did not
\end{abstract}


cause redness and at The dry time test of all preparations met the requirements, namely under 30 minutes. The microbial test against Propianibacterium acne showed a good inhibition zone on the F2 mask preparation, which was $16 \mathrm{~mm}$. The conclusion is that papaya leaf ethanol extract combined with pumpkin ethanol extract shows that it can be used as an alternative to cosmetics and can be used as a reference for use as natural cosmetics.

Keywords: combination, papaya leaf, pumpkin, preparation, clay mask

\section{PENDAHULUAN}

Masker kulit wajah merupakan salah satu jenis kosmetika tradisional yang dapat digunakan sebagai perawatan wajah untuk mempertahankan kesehatan kulit wajah. Masker kulit wajah bermanfaat untuk meningkatkan taraf kebersihan kulit, kesehatan kulit, kecantikan kulit, memperbaiki dan merangsang kembali kegiatan sel-sel kulit. Bahan yang diperlukan untuk membuat masker kulit wajah pada umumnya bertujuan untuk menyegarkan, mengencangkan kulit, dan sebagai antioksidan (Muliana D, 2013).

Daun pepaya yang selama ini dikenal karena rasanya yang pahit mengandung enzym papain. Enzim papain untuk mengangkat sel kulit mati hingga menampakkan lapisan kulit baru yang segar karena dapat meningkatkan produksi asam amino yang meremajakan kulit dan mengelupas kulit mati, sehingga kulit tampak awet muda. Daun pepaya mengandung enzim papain yang berperan sebagai exfoliating agent yang mampu mengangkat sel kulit mati dan sel kulit kering sehingga kulit tampak segar dan bercahaya. Pengelupasan adalah pengelupasan kulit. Selain mengandung vitamin dan antioksidan, juga membantu kulit menjadi awet muda (Marttawi M, 2014).

Labu kuning meruakan sumber vit. C yang merupakan antiogsidan kuat. Labu kuning juga mengandung beta-kereton yang membantu mengatasi kerusakan akibat sinar UV dan memperbaiki tekstur kulit dan melindungi kulit dari kerusaksn radikal yang menyebabkan keriput (Gardjito, 2006).

Hasil penelitian Hasrianti, 2019 yang berjudul Formulasi Sediaan Masker Clay Dari Ekstrak Etanol Daun Pepaya (Carica papaya L) Dan Sari Buah Belimbing Wuluh (Averrhoa bilimbi L.) menyatakan Ekstrak etanol daun pepaya dan sari buah belimbing wuluh dapat diformulasikan didalam sediaan masker clay dengan variasi konsentrasi masing-masing 5\%, $10 \%$ dan $15 \%$.

Dan hasil penelitian Cynthia et al, 2018 yang berjudul Formula Sediaan Masker Wajah Ekstrak Labu Kuning (Cucurbita moschata) Bentuk Clay Menggunakan Bentonit Dan Kaolin Sebagai Clay Mineral tujuan dilakukan penelitian ini untuk membuktukan bahwa senyawa aktif berasiat pada ekstrak dan sedian masker clay yang dingunakan, dimana hasil tersebut menunjukkan bahwa beta-karoten terdapat pada ekstrak dengan $R F(0,86)$ yang mendekati $\mathrm{Rf}$ teritis beta-karoten yaitu 0,8-1 (schiedt, 1995). Hasil efaluasi fisik dan evaluasi masker clay ke 4 formula telah memenuhi spesifikasi organoleptis dan berufat homogeny. Berdasarkan data viskositas masker, diperoleh persamaan kolinomial, faktor bentonin kaolin terhadap nilai viskositas berpengaruh sikifikan, dengan nilai $\mathrm{F}_{\text {hitung }}$ masing masing $(30258,16 ; 47780,89)>\mathrm{F}_{0,05}(1,4)=7,71$ dan interaksi yang di hasilkn kedua faktor tesebut yaitu bentonit dan koalin berpengaruh signifikan terhadap nilai viskositas dengan nilai $F_{\text {hitung }} 17999,61>\mathrm{F}_{0,05}(1,4)=7,71$.

Berdasarkan informasi diatas maka saya tertarik untuk melakukan penelitian tentang formulasi sediaan masker clay dari ekstrak etanol daun pepaya (Carica papaya L.) kombinasi labu kuning (Cucurbita moschata.) sebagai perawatan kecantikan. 


\title{
METODE PENELITIAN
}

\section{Bahan}

Bahan yang digunakan dalam penelitian ini adalah ekstrak daun pepaya, ektrak labu kuning yang diproleh dari desa Parigi Kec. Dolok, Kab, Padanglawas Utara, Medan Sumatra Utara, gliserin, air suling (aquadest), Bentonit, Kaolin Natrium Metabisulfit, TiO2, Nipagin, Sodium Lauril Sulfat dan Xantan Gum, Etanol 70\%.

\begin{abstract}
Alat
Alat-alat yang digunakan dalam penelitian ini adalah timbangan digital, ayakan mesh, blender, lumpang, alu, spatula, gelas ukur, sudip (kertas rongen), pipet tetes, kertas perkamen, objek glass, $\mathrm{pH}$ meter, beaker glass, pisau, dan wadah.

\section{Pembuatan Ekstrak Daun Pepaya (Carita papaya L.) Dan Labu Kuning (Cucurbita moschata)}

Sebanyak 500 g serbuk simplisia daun papaya dan labu kuning dimasukkan ke dalam wadah gelas berwarna gelap secara terpisah lalu dimaserasi dengan 7,5 bagian pelarut etanol $70 \%$ setiap wadah dalam 5 hari terlindung dari cahaya matahari sambil sering diaduk, setelah 5 hari hasil masing masing maserasi disaring dan diperas dengan kertas saring, ampasnya ditambahkan cairan penyari secukupnya sehingga diperoleh seluruh maserat sebanyak 2 liter. Kemudian setiap maserat didiamkan selama 2 hari dan endapan tuangkan. Setiap Maserat diuapkan dengan bantuan alat penguap rotari evaporator pada temperatur tidak lebih dari $70^{\circ} \mathrm{C}$ sampai diperoleh ekstrak kental (Ginting, 2017).
\end{abstract}

\section{Karakterisasi Simplisia}

\section{a. Uji Kadar Air}

Penetapan kadar air dilbuat secara pemanasan. Serbuk ditimbang sebanyak 2 gram dalam cawan yang telah diketahui beratnya. Kemudian keringkan dalam oven pada suhu $100-105^{\circ} \mathrm{C}$ selama 3-5 jam. Kemudian dinginkan dan timbang. Panaskan lagi dioven selama 30 menit, dinginkan dan ditimbang. Pengurangan berat merupakan banyaknya air dalam bahan (Maharani,2013).

$$
\text { Kadar air }=\frac{b-c}{a} \times 100 \%
$$

\section{b. Uji Kadar Abu Total}

Dalam 2 gram ekstrak kering di timbang, dimasukkan kedalam krus porselin yang telah dipijarkan dan ditara, diratakan. Pijarkan pelahan-lahan hingga arang habis, didinginkan dan ditimbang. Jika dengan cara ini arang tidak dapat hilang, tambahkan air panas, saring melalui kertas saring bebas abu, pijarkan sisa dan kertas saring dalam krus yang sama. Masukkan filtrat kedalam krus, uapkan setelah itu pijarkan hingga bobot tetap, timbang. Hitung kadar abu terhadap bahan yang telah dikeringkan diudara (Depkes RI, 2000).

$$
\text { Kadar abu total }=\frac{b-c}{a} \times 100 \%
$$

\section{c. Uji Kadar Abu Tidak Larut Asam}

Abu yang didapat pada penetapan kadar abu, dididihkan selama $25 \mathrm{ml}$ asam klorida encer selama 5 menit, kumpulkan bagian yang tidak larut asam. Saring melalui kurs 
kaca masir atau kertas saring bebas abu, cuci dengan air panas, pijarkan hingga bobot tetap, lalu ditimbang. Hitung kadar abu yang tidak larut dalam asam bahan yang telah dikeringkan diudara (Depkes RI, 2000).

$$
\text { Kadar abu tidak larut asam }=\frac{w o-w 2}{w 1} \times 100 \%
$$

\section{d. Penetapan Kadar Sari tidak Larut Dalam Air}

Sebanyak 5 g serbuk simplisia, dimaserasi selama 24 jam dalam $100 \mathrm{ml}$ airkloroform 2,5 ml kloroform dalam air suling sampai 1 liter) dalam labu bersumbat sambil dikocok sesekali selama 6 jam pertama, kemudian dibiarkan selama 18 jam, lalu disaring. jumlah $20 \mathrm{ml}$ filtrat pertama diuapkan sampai kering dalam cawan penguap yang berdasar rata yang telah ditara dan sisa dipanaskan pada suhu $105^{\circ} \mathrm{C}$ sampai didapat bobot tetap. Kadar sari yang larut dalam air dihitung terhadap bahan yang telah dikeringkan (Ditjen POM, 1995).

\section{Kadar sari larut dalam air $=\frac{w o-w 2}{w 1} \times F$.pengenceran $X 100 \%$}

\section{e. Penetapan Kadar Sari Yang didalam Larut Etanol}

$5 \mathrm{~g}$ serbuk simplisia dimaserasi selama 24 jam dalam $100 \mathrm{ml}$ etanol $96 \%$ dalam labu bersumbat lalu dikocok sesekali selama 6 jam pertama, kemudian dibiarkan 18 jam. Larutan tersebut disaring cepat untuk menghindari penguapan etanol. Sejumlah 20 $\mathrm{ml}$ filtrat diuapkan hingga kering dalam cawan penguap yang berdasar rata yang telah dipanaskan dan ditara.Sisa dipanaskan pada suhu $105^{\circ} \mathrm{C}$ sampai diperoleh bobot tetap .Kadar sari yang larut dalam etanol $96 \%$ dihitung terhadap bahan yang telah dikeringkan (Ditjen POM, 1995).

Kadar sari tidak larut etanol $=\frac{w o-w 2}{w 1} \times F \cdot$ pengenceran $\mathrm{X} 100 \%$

\section{Skrining Fitokimia}

\section{a. Uji Flavonoid}

Uji flavonoid menurut Depkes (1995), $1 \mathrm{~mL}$ ekstrak dilarutkan dengan $1 \mathrm{~mL}$ etanol 95\%. Kemudian ditambahkan dengan $0,1 \mathrm{~g}$ serbuk $\mathrm{Mg}$ dan 10 tetes $\mathrm{HCl}$ pekat, kemudian dikocok kuat-kuat. Uji positif ditunjukan dengan terbentuknya warna merah, kuning atau jingga (Depkes, 1995).

\section{b. Uji Saponin}

Uji saponin dilakukan dengan dinambahkan $1 \mathrm{~mL}$ ekstrak yang diencerkan menggunakan aquades pada volume sama. Dituangkan ke dalam tabung reaksi, lalu dikocok selama 15 menit. Hasil positif ditunjukkan adanya buih yang stabil selama 5 menit (Depkes, 1987).

\section{c. Uji Alkaloid}

Uji alkaloid menurut Harborne (1996) dilakukan dengan cara menambahkan setiap ekstrak sebanyak $10 \mathrm{~mL}$ dengan $1,5 \mathrm{~mL} \mathrm{HCl} 2 \mathrm{~N}$, dipanaskan selama 5 menit kemudian disaring. Hasil saringan ditambahkan dengan 5 tetes pereaksi Mayer. Hasil positif adanya alkaloid ditunjukkan dengan terbentuknya endapan endapan coklat (Depkes, 1995). 


\section{d. Uji Terpenoid (Metode Lieberman-Burchard)}

Uji terpenoid dilakukan menggunakan metode Lieberman-Burchard (Juwati 1998). Sebanyak $50 \mathrm{mg}$ ekstrak ditambahkan dengan 5 tetes asam asetat anhidrat lalu dikocok. Kemudian, ditambahkan 2 tetes $\mathrm{H} 2 \mathrm{SO} 4$ pekat, kocok dan diamati. Hasil positif ditunjukkan oleh terbentuknya warna merah menandakan adanya terpenoid (Rohman, 2014).

\section{e. Uji Tanin}

dilakukan dengan diengencerkan $1 \mathrm{~mL}$ ekstrak dengan $2 \mathrm{~mL}$ aquades. Setelah itu, ditambahkan 3 tetes larutan $\mathrm{FeCl} 3$. Hasil positif ditunjukkan oleh terjadinya perubahan warna larutan menjadi biru kehitaman atau hijau kehitaman (Depkes, 1987).

\section{f. Uji Glikosida}

Pengujian dengan reaksi Liebermann Burchard dilakukan dengan cara sebanyak $1 \mathrm{~g}$ ekstrak kental daun putri malu dalam cawan porselin, ditambahkan dengan $5 \mathrm{~mL}$ asam asetat anhidrat P. Asam sulfat P ditambahkan 10 tetes, terjadi warna biru atau hijau menunjukkan adanya glikosida (Rohman, 2014).

\section{Pembuatan Masker Clay Dari Ekstrak Daun Pepaya (Carita papaya L.) Dan Labu Kuning (Cucurbita moschata)}

Formulasi standar yang digunakan:

R/Bentonite 1 to $8 \%$

Xantan Gum 0,1 to $1,0 \%$

Kaolin 5 to $40 \%$

Gliserin 2 to $10 \%$

Sodium Lauril Sulfat 2 to $20 \%$

$\mathrm{TiO} 2<1 \%$

Nipagin $<1 \%$

Parfum q.s

Aquadest ad 100\% (Depkes Ri, 1978).

Konsentrasi ekstrak daun pepaya yang digunakan adalah 2\%, 4\%, 6\%, dan labu kuning dengan konsentrasi $6 \%, 4 \%$ dan $2 \%$. Formula dasar masker yang tidak mengandung ekstrak digunakan sebagai blanko. Cara pembuatannya ekstrak ditimbang sesuai dengan konsentrasi, kemudian ditambahkan dengan basis masker clay yang telah dibuat hingga $100 \mathrm{~g}$ dan digerus merata hingga terbentuk pasta homogen.

\section{Pengujian Terhadap Masker Clay}

a. Pengujian $\mathbf{p H}$

Pada sediaan ditambahkan air hingga membentuk pasta kemudian diukur $\mathrm{pH}$ sediaan. Pengukuran $\mathrm{pH}$ dilakukan dengan cara mencelupkan $\mathrm{pH}$ meter sampai batas yang telah ditentukan ke dalam sediaan masker sebnyak $1 \mathrm{~g}$ yang telah diencerkan dengan $100 \mathrm{ml}$ aquades. Pengamatan dilihat secara langsung warna, bau dan tekstur dari sediaan masker clay yang diamati secara visual.

b. Pengujian Homogenitas

Pengujian homogenitas sediaan dilakukan dengan cara sampel dioleskan pada sekeping kaca atau bahan transparan lain yang cocok, sediaan harus menunjukkan susunan yang homogendan tidak terlihat adanya butiran kasar. 


\section{c. Pemeriksaan Organoleptik}

Pengamatan dilihat secara langsung warna, bau dan tekstur dari sediaan masker clay yang diamati secara visual.

\section{d. Pengujian Mikroba}

Uji aktivitas antibakteri, Sebanyak $0,1 \mathrm{ml}$ inokulum dimasukkan ke dalam cawan petri steril, setelah itu dituang media nutrient agar sebanyak $15 \mathrm{ml}$ dengan suhu $45-50^{\circ} \mathrm{C}$, selanjutnya dihomogenkan dengan cara digoyang membentuk angka 8 , agar media dan suspensi bakteri tercampur rata. Pada media yang telah dibuat lobang seperti sumuran sediaan masker clay ekstrak etanol daun pepaya kombinasi labu kuning dengan formulasi F0, f1, f2, f3, dan dibandingkan dengan kontrol ngatif, dan kontrol positif yaitu sediaan dipasaran, kemudian diinkubasi dalam inkubator pada suhu $37^{\circ} \mathrm{C}$ selama 18 - 24 jam, setelah itu diukur diameter daerah hambatan (zona jernih) pertumbuhan di sekitar pencadang dengan menggunakan jangka sorong.

e. Uji Waktu Sediaan Mengering

Pengujian waktu mengering bertujuan untuk mengetahui berapa lama masker mengering pada permukaan kulit, Pengukuran lama pengeringan dilakukan pad suhu $\pm 25^{\circ} \mathrm{C}$ dengan mengambil $\pm 2 \mathrm{~g}$ sediaan masker dan dioleskan pada wajah sukarelawan, ditandai lalu diukur waktu saat sediaan mengering.

\section{f. Uji Iritasi Pada Sukarelawan}

Uji iritasi dilakukan terhadap 6 orang relawan yang dipilih secara rendom dengan teknik patch test yaitu uji tempel terbuka yang dilakukan dengan mengoleskan sediaan (FI, FII dan FIII) seluas $2,5 \mathrm{~cm}^{2}$ di belakang telinga suka relawan dibiarkan terbuka dan diamati apa yang terjadi. Gejala yang timbul diamati, umumnya Reaksi iritasi positif ditandai oleh adanya kemerahan, gatal-gatal, atau bengkak pada kulit yang diberi perlakuan.

\section{HASIL DAN DISKUSI}

Berdasarkan hasil pemeriksaan karakterisasi simplisia dari tumbuhan daun papaya dan labu kuning bahwa kadar air memenuhi persyaratan yaitu $10 \%$. Kadar sari larut etanol diperoleh 19,333\% dan kadar sari larut dalam air 1,5\% maka dapat disimpulkan kandungan senyawa yang terdapat dalam simplisia daun papaya mengandung zat bersifat polar. Kadar abu total dan kadar abu tidak larut asam ditetapkan untuk melihat zat organik, hasil yang didapat dari kadar abu total yaitu 5,333\% dan kadar abu tidak larut asam yaitu $22 \%$ pada hasil uji krakterisasi daun pepaya memenuhi mutu standar. Sebagaimana yang ditunjukkan oleh tabel 1.

Tabel 1. Hasil karakterisasi daun pepaya

\begin{tabular}{clcccc}
\hline No & Parameter pemeriksaan & Hasil (\%) & Standar\% & Memenuhi & $\begin{array}{c}\text { Tidak } \\
\text { Memenuhi }\end{array}$ \\
\hline 1. & Kadar air & 10 & $<10$ & $\checkmark$ & - \\
\hline 2. & Kadar abu total & 5,333 & $<6$ & $\checkmark$ & - \\
\hline 3. & Kadar sari larut dalam air & 1,5 & $<1,5$ & $\checkmark$ & - \\
\hline 4. & $\begin{array}{l}\text { Kadar sari larut dalam } \\
\text { etanol }\end{array}$ & 19,333 & $>18$ & $\checkmark$ & - \\
\hline 5. & $\begin{array}{l}\text { Kadar sari tidak larut } \\
\text { asam }\end{array}$ & 22 & $>12.5$ & $\checkmark$ & \\
\hline
\end{tabular}


Berdasarkan hasil Karakterisasi kadar air memenuhi persyaratan yang ditetapkan Materia Medika Indonesia tidak lebih dari 10\%, bila melebihi $10 \%$ akan mudah ditumbuhi mikroba dan rusak dalam penyimpnan. Kadar sari ditetapkan untuk mengetahui kandungan senyawa polar dan non polar. Simplisia labu kuning memiliki kadar air 8,5\%, Kadar sari larut dalam air 1,333\% dan larut dalam etanol 20\%, maka dapat disimpulkan labu kuning kandungan zat bersifat polar. Kadar abu total dan kadar abu tidak larut asam ditetapkan untuk dapat melihat zat organik yang terdapat dalam simplisia, hasil yang didapat kadar abu total yaitu 5\% dan kadar abu tidak larut asam yaitu 13,66\%.dapat dilihat pada tabel 2.

Tabel 2. Hasil Karakterisasi Labu Kuning

\begin{tabular}{clcccc}
\hline No & Parameter pemeriksaan & $\begin{array}{c}\text { Hasil } \\
(\boldsymbol{\%})\end{array}$ & Standar\% & Memenuhi & $\begin{array}{c}\text { Tidak } \\
\text { Memenuhi }\end{array}$ \\
\hline 1. & Kadar air & 8,5 & $<10$ & $\checkmark$ & - \\
\hline 2. & Kadar abu total & 5 & $<6$ & $\checkmark$ & - \\
\hline 3. & Kadar sari larut dalam air & 1,333 & $<1,5$ & $\checkmark$ & - \\
\hline 4. & $\begin{array}{l}\text { Kadar sari larut dalam } \\
\text { etanol }\end{array}$ & 20 & $>18$ & $\checkmark$ & - \\
\hline 5. & $\begin{array}{l}\text { Kadar sari tidak larut } \\
\text { asam }\end{array}$ & 13,66 & $>12.5$ & $\checkmark$ & - \\
\hline
\end{tabular}

Berdasarkan hasil uji skrinig fitokimia yang dihasilakan oleh simplisia labu kuning, menunjukan hasil yang positif pada uji skrining fitokimia uji Alkaloid, Flavonoid, Saponin dan Glikosida, kemudian dalam uji Tanin dan uji Teroid menunjukkaan hasil negatif. Untuk hasil skrining fitokimia dari simplisia daun papaya menunjukkan hasil yang positif pada uji skrining fitokimia uji Alkaloid, Flavonoid, Saponin, Tanin, namun pada uji Glikosida dan Stroid menunjukkan hasil negatif dapat dilihat pada tabel 3 .

Tabel 3. Hasil uji skrining fitokimia daun pepaya dan labu kuning

\begin{tabular}{clcc}
\hline No & \multicolumn{1}{c}{ Golongan Senyawa } & Daun Pepaya & Labu Kuning \\
\hline 1 & Alkaloid & + & + \\
\hline 2 & Flavonoid & + & + \\
\hline 3 & Saponin & + & + \\
\hline 4 & Tanin & + & - \\
\hline 5 & Uji glikosida & - & + \\
\hline 6 & Uji Steroid & - & - \\
\hline
\end{tabular}

Berdasarkan hasil pemeriksaan homogenitas terhadap sediaan masker clay yang diformulasi menunjukkan bahwa semua sediaan tidak memperlihatkan adanya butir-butir kasar pada saat sediaan dioleskan pada kaca transparan. Hal ini menunjukkan bahwa sediaan yang dibuat memiliki susunan yang homogen (Ditjen POM RI, 1979).dapat dilihat pada tabel 4.

Tabel 4. Hasil Uji Homogenitas

\begin{tabular}{ccc}
\hline No & Formula & Hasil pengamatan \\
\hline 1 & F0 & Homogen \\
\hline 2 & F1 & Homogen \\
\hline 3 & F2 & Homogen \\
\hline 4 & F3 & Homogen \\
\hline
\end{tabular}


Berdasarkan dari hasil uji Pengukuran $\mathrm{pH}$ sediaan diukur dengan menggunakan $\mathrm{pH}$ universal dengan. Untuk pemeriksaan $\mathrm{pH}$ sediaan masker clay, didapat $\mathrm{pH}$ berkisar antara 6-7. Persyaratan pH yang diizinkan adalah 5-8 (Harry, 2000). Hasil pengamatan menunjukkan $\mathrm{pH}$ sediaan masker clay yang diformulasi masih memenuhi persyaratan yang diizinkan. Kestabilan $\mathrm{pH}$ merupakan salah satu parameter penting yang menentukan stabil atau tidaknya suatu sediaan. Derajat keasaman $(\mathrm{pH})$ merupakan pengukuran aktivitas hydrogen dalam lingkungan air. Nilai $\mathrm{pH}$ tidak boleh terlalu asam karena itu dapat menyebabkan iritasi pada kulit sedangkan nilai $\mathrm{pH}$ terlalu basa dapat menyebabkan kulit bersisik dapat dilihat pada tabel 5 .

Tabel 5. Hasil uji pH

\begin{tabular}{ccc}
\hline No & Sediaan Masker Clay & pH \\
\hline $\mathbf{1}$ & F0 & 6 \\
\hline $\mathbf{2}$ & F1 & 7 \\
\hline $\mathbf{3}$ & F2 & 7 \\
\hline $\mathbf{4}$ & F3 & 7 \\
\hline
\end{tabular}

Hasil Pengujian pengamatan organoleptik dilakukan pada perubahan bentuk, warna dan bau sediaan. Pengamatan ini dilakukan secara visual. Hasil pengamatan stabilitas sediaan stabilitas fisik sediaan masker clay selama waktu penyimpanan tidak menunjukkan perubahan yang signifikan terhadap bentuk, warna dan bau sediaan tersebut.dapat dilihat pada tabel 6 .

Tabel 6. Hasil uji organoleptik

\begin{tabular}{ccccc}
\hline No & Formula & Bau & Bentuk & Warna \\
\hline & F0 & Tidak berbau & Semi padat & Putih \\
\hline 1 & F1 & Khas labu & Semi padat & Kecoklatan \\
\hline 2 & F2 & Khas labu & Semi padat & Kecoklatan \\
\hline 3 & F3 & Khas pahit & Semi padat & Kecoklatan \\
\hline
\end{tabular}

Berdasarkan hasil uji aktivitas bakteri Propionibacterium acne pada sediaan masker clay F0 (blanko) menghasilkan aktivitas dengan zona hambat $20 \mathrm{~mm}$ yang semakin besar. Kemudian pada sediaan pasta F1 $11 \mathrm{~mm}$ dan F2 menghasilkan aktivitas dengan zona hambat $16 \mathrm{~mm}$. Pada sediaan F3 $15 \mathrm{~mm}$ menghasilkan zona hambat. sedangkan pada control positif menghasilkan zona hambat $23 \mathrm{~mm}$. uji aktivitas yang paling baik terdapat pada F2 karena memiliki daya hambat yang paling besar dibandingkan sediaan yang lain. Menurut Farmakope Indonesia V (2014), zona hambat efektif apabila menghasilkan kurang lebih $14 \mathrm{~mm}$. Diameter zona hambat $5 \mathrm{~mm}$ atau kurang dikatatakan lemah, zona hambat 5 - $10 \mathrm{~mm}$ dikatakan sedang, zona hambat 10 $20 \mathrm{~mm}$ dikatakan kuat, dan zona hambat $20 \mathrm{~mm}$ atau lebih dikatakan sangat kuat. Dapat dilihat pada tabel 7 .

Tabel 7. Hasil uji mikroba

\begin{tabular}{clc}
\multirow{2}{*}{ No } & \multicolumn{1}{c}{ Sediaan } & \begin{tabular}{c} 
Diameter daerah hambatan $(\mathbf{m m})^{*}$ \\
\cline { 2 - 3 }
\end{tabular} \\
\hline 1 & Planko & 20 \\
\hline 2 & Masker F1 & 11 \\
\hline 3 & Masker F2 & 16 \\
\hline 4 & Masker F3 & 15 \\
\hline 5 & Kontrol positif & 23 \\
\hline
\end{tabular}


Pengujian waktu kering bertujuan untuk mengetahui berapa lama masker mengering pada permukaan kulit dan membentuk lapisan film. Waktu kering dari kelima formula gel masker clay berkisar antara 9 menit sampai 25 menit. Formula yang tidak mengandung ekstrak daun papaya yang dikombinasi dengan labu kuning (F0) memiliki waktu kering yang lebih cepat dibandingkan dengan ke tiga formula yang mengandung ekstrak daun pepaya yang dikombinasi dengan labu kuning yang berbeda (F1), (F2), (F3). Hal ini mungkin disebabkan karena penambahan ekstrak yang bervariasi sehingga memperlambat penguapan etanol, dari data yang diperoleh ke empat formula masker clay semua memenuhi persyaratan waktu kering masker clay yang baik antara 15-30 menit (Lestari, 2013) dapat dilihat pada tabel 8.

Tabel 8. Uji waktu kering

\begin{tabular}{ccccc}
\hline \multirow{2}{*}{ Pengukuran } & \multicolumn{4}{c}{ Waktu kering (menit) } \\
\cline { 2 - 5 } & F0 & F1 & F2 & F3 \\
\hline 1 & 10 & 19 & 20 & 25 \\
\hline 2 & 10 & 19 & 23 & 25 \\
\hline 3 & 9,8 & 20 & 20 & 27 \\
\hline Rata-rata & $\mathbf{9 , 3}$ & $\mathbf{1 9 , 3}$ & $\mathbf{2 1}$ & $\mathbf{2 5}$ \\
\hline
\end{tabular}

Menurut Wasitaatmadja (1997), uji iritasi kulit yang dilakukan untuk mengetahui efek samping pada kulit, dengan memakai kosmetika di bagian bawah lengan atau belakang telinga dibiarkan selama 24 jam. Dari data tabel 4.9, tidak terlihat adanya efek samping berupa kemerahan, gatal-gatal, ataupun adanya pembengkakan pada kulit yang ditimbulkan oleh sediaan dapat dilihat pada tabel 9.

Tabel 9. Uji iritasi

\begin{tabular}{lcccccc}
\hline \multirow{2}{*}{ Pengamatan } & Blanko & F0 & F1 & F2 & F3 & $\begin{array}{c}\text { Kontrol } \\
\text { Positif }\end{array}$ \\
\cline { 2 - 7 } & - & - & - & - & - & - \\
\hline Kemerahan & - & - & - & - & - & - \\
\hline Bengkak & - & - & - & - & - & - \\
\hline
\end{tabular}

\section{KESIMPULAN}

Berdasarkan hasil penelitian yang dilakukan dapat disimpulkan ekstrak etanol daun pepaya dan ekstrak labu kuning dapat diformulasikan dalam sediaan masker clay. Sediaan masker clay ekstrak etanol daun pepaya dan kombinasi labu kuning dapat mencerahkan wajah.Kombinasi ekstrak etanol daun pepaya dan ekstrak labu kuning dapat disediaansikan dalam sediaan masker cla dan memenuhi syarat mutu pada evaluasi sediaan.

\section{REFERENSI}

Departemen Kesehatan Republik Indonesia., 2000. Farmakope indonesia. Edisi IV Jakarta : Depkes RI.

Departemen Kesehatan Republik Indonesia.,1978. Farmularium nasional. Edisi II Jakarta : Depkes RI. 
Depkes. 1995b. Materia Medika Indonesia. Jilid VI. Jakarta: Departemen Kesehatan Republik Indonesia. Halaman 50-54, 300-304.

Ditjen POM. 1995. Farmakope indonesia Edisi IV. Jakarta: Departemen Kesehatan RI. Hal. 1112-1116.

Gardjito, M. 2006. 'Labu Kuning Sumber Karbohidrat Kaya Vitamin A'. Yogyakarta : Tridatu Visi Komunikasi.

Ginting, O. S. 2017. Perbandingan Aktivitas Antibakteri Ekstrak Etanol Biji Pepaya (Carica papaya L.) dari dua Varietas Terhadap bakteri Escherichia coli. Jurnal, vol 1 no 2

Harry, R. G. 2000. Harry's Cosmeticology. Edisi VIII. Newyork: Chemical Publishing Co. Inc halaman 471-483.

Hernani., M, Rahardjo. 2006. "Tanaman Berkhasiat Antioksidan”. Penebar Swadaya. Jakarta.

Khairunnisa, n. 2018. "Formulasi Sediaan Masker Gel Ekstrak Etanol Biji Jagung (Zea mays L.)". Institut Kesehatan Helvetia;

Lestari, P.M., Sutyasningsih, R. B. and Ruhimat. 2013. The Influence of Increase Concentration Polivinil Alcohol (PVA) As a Gelling Agent on Physical Properties of The Peel-Off Gel Of Pineapple Juice (Ananas comosus L.). Asian Societies of Cosmetic Scientists Conference. P. 127

Maharani, 2013. Organizational citizenship behavior role in mediating the effect of transformational leadership, job satisfaction on employee performance: studiesin PT bank syariah mandiri malang East Java. Internasional Journal of business and Management; Vol. 8, No. 17; 2013.

Wasitaatmadja, 1997, Penuntun Kosmetik Medik, Universitas Indonesia, Jakarta. 